\title{
STUDI EKSPLORASI LIMBAH GENTENG ASAL GODEAN SEBAGAI BAHAN TAMBAH PADA CAMPURAN BETON
}

\author{
Oleh: Hery Kristiyanto ${ }^{1}$ dan Pri Susmanto ${ }^{2}$ \\ E-mail: heryjogja90@gmail.com
}

\begin{abstract}
ABSTRAK: Daerah Godean merupakan daerah pengrajin genteng yang cukup produktif setiap harinya pabrik-pabrik genteng di daerah Godean memproduksi genteng dengan jumlah yang cukup besar, dan tidak semua genteng yang dihasilkan bermutu baik, banyak genteng yang tidak dapat dimanfaatkan dikarenakan beberapa factor diantaranya genteng pecah pada saat pembakaran, pecah pada saat pembongkaran dan juga genteng melengkung karena pemanasan yang berlebihan. Tujuan dari penelitian ini adalah untuk memanfaatkan limbah pecahan genteng yang tidak dapat didaur ulang di lingkungan pabrik genteng di daerah Godean yang semakin menumpuk sehingga mengganggu lingkungan sekitar. Diharapkan juga dari penelitian ini dapat diketahui apakah pecahan genteng dapat dijadikan alternatif bahan tambah yang baik atau sebaliknya dengan penambahan pecahan genteng dapat merusak mutu beton.

Penelitian ini dilakukan di Laboratorium Bahan Konstruksi Teknik Universitas Cokroaminoto Yogyakarta dan Laboratorium Bahan Konstruksi Teknik Universitas Atma Jaya Yogyakarta. Agregat yang digunakan adalah pasir dari Kali Gendol dan batu pecah dari Clereng dengan ukuran maksimal $40 \mathrm{~mm}$, faktor air semen 0,48, bahan tambah yang digunakan adalah pecahan genteng dengan prosentase penambahan $0 \%, 25 \%, 50 \%, 75 \%$, dan 100\% terhadap agregat kasar. Pengujian yang dilakukan adalah kuat tekan dengan menggunakan cetakan silinder dengan ukuran diameter $15 \mathrm{~cm}$ dan tinggi $30 \mathrm{~cm}$, dan kuat lentur dengan cetakan balok dengan ukuran 15 x 15 x $60 \mathrm{~cm}$. Pengujian dilakukan pada beton umur 28 hari.
\end{abstract}

Dari hasil penelitian diperoleh bahwa kuat tekan beton maksimal terjadi pada penambahan pecahan genteng $25 \%$ dengan nilai $67,31 \%$ dari kuat tekan beton normal sedangkan kuat lentur maksimal terjadi pada penambahan pecahan genteng $75 \%$ dengan nilai $93,12 \%$ dari kuat lentur beton normal. Berat jenis beton pada penambahan pecahan genteng 75\% adalah $1977 \mathrm{~kg} / \mathrm{m} 3$ sehingga dapat dikatagorikan sebagai beton ringan.

Kata kunci : berat volume, kuat lentur, kuat tekan, pecahan genteng

\section{PENDAHULUAN}

Melambungnya harga-harga bahan bangunan seperti semen, pasir, kerikil dan bahan lainnya, menyebabkan menurunnya daya beli masyarakat, sementara kebutuhan akan agregat halus dan agregat kasar tersebut setiap tahunnya terus meningkat seiring dengan laju perkembangan pembangunan di Indonesia. Permasalahan tersebut memerlukan solusi yang diantaranya adalah dengan penggunaan bahan susun beton altenatif yang harganya murah berupa sisa material yang sampai saat ini masih menjadi limbah. Bahan susun pada beton sangat berpengaruh pada mutu beton yang akan dihasilkan, untuk itu perlu ada pemilihan bahan susun yang baik sehingga dapat diperoleh mutu beton yang memadai.

Pecahan genteng adalah material yang selama ini belum dimanfaatkan secara optimal dan cenderung bersifat sebagai limbah industri. Untuk itu perlu dilakukan penelitian dalam usaha meningkatkan manfaat pecahan genteng terutama sebagai pengganti agregat kasar dalam campuran beton.

\subsection{BATASAN MASALAH}

Limbah pecahan genteng sokka yang digunakan berasal dari Godean yang berukuran maksimal $3 \mathrm{~cm}$.

1) adalah staf pengajar Program Studi Teknik Sipil Universitas Cokroaminoto Yogyakarta

2) adalah mahasiswa Program Studi Teknik Sipil Universitas Cokroaminoto Yogyakarta

Studi Eksplorasi Limbah Genteng Asal Godean Sebagai Bahan Tambah Pada

Campuran Beton (Hery Kristiyanto) 
Variasi penambahan pecahan genteng pada adukan beton mulai dari $0 \%, 25 \%$, $50 \%, 75 \%$ dan $100 \%$ terhadap volume kerikil, dengan factor air semen 0,48 . Penelitian dilakukan hanya terbatas pada kuat tekan, kuat lentur dan serapan air.

Benda uji tekan dan modulus elastisitas untuk setiap variasinya berbentuk silinder sebanyak tiga buah dengan ukuran diameter $15 \mathrm{~cm}$ dan tinggi $30 \mathrm{~cm}$, dan benda uji lentur berbentuk persegi panjang sebanyak dua buah untuk setiap variasinya dengan ukuran lebar $15 \mathrm{~cm}$, tinggi $15 \mathrm{~cm}$, dan panjang $60 \mathrm{~cm}$ dan diberi tulangan besi beton $\varnothing 10$ sebanyak dua buah tiap benda uji. Pengujian kuat tekan dilakukan pada umur beton 14 dan 28 hari, sedangkan pengujian kuat lentur dilakukan pada umur beton 28 hari.

\title{
2. LANDASAN TEORI
}

\subsection{Kuat tekan}

Sifat yang paling penting dari beton adalah kuat tekan. Beton pada umumnya lebih baik jika kuat tekannya lebih tinggi, Kardiyono Tjokrodimulyo, (1996). Nilai uji yang diperoleh dari setiap benda uji akan berbeda karena beton merupakan material heterogen yang kekuatannya dipengaruhi oleh proporsi campuran, bentuk dan ukuran, kecepatan pembebanan dan oleh kondisi lingkungan pada saat pengujian. Oleh karena itu metode statistik diperlukan untuk menentukan kekuatan tekan karakteristik beton fc', yang didefinisikan sebagai kekuatan tekan beton yang dilampaui oleh paling sedikit $95 \%$ dari benda uji. Nilai fc' adalah kekuatan tekan benda uji silinder berdiameter $150 \mathrm{~mm}$ dan panjang $300 \mathrm{~mm}$ sebagaimana ditetapkan dalam SNI T - 15 - 1991. Pengujian standarnya didasarkan atas kekuatan beton umur 28 hari. Untuk menentukan kuat tekan beton rumus yang digunakan adalah sebagai berikut :

$$
\mathrm{fc}^{\prime}=\frac{\mathrm{P}}{\mathrm{A}}
$$

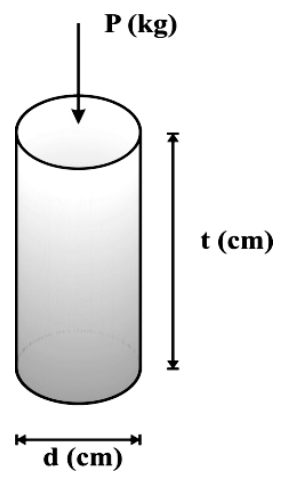

Gambar 1 Gambar uji tekan pada pembebanan silinder.

\author{
Dengan : \\ $\mathrm{fc}^{\prime}$ : Kuat tekan / kuat desak $\left(\mathrm{kg} / \mathrm{cm}^{2}\right)$. \\ $\mathrm{P}$ : Beban maximum $(\mathrm{kg})$. \\ A : Luas tampang $\left(\mathrm{cm}^{2}\right)$.
}




\subsection{Kuat lentur}

Kuat lentur merupakan salah satu dari sifat penting beton. Kuat lentur terbentuk akibat interaksi antara unsur-unsur pembentuknya yaitu semen, pasir, kerikil dan air. Penambahan kekuatan ini dipengaruhi oleh beberapa faktor seperti bahan dasar, proses pengolahan dan perawatan. Pengujian kuat lentur dilakukan dengan membuat benda uji berupa balok beton dengan ukuran standar panjang 500 $\mathrm{mm}$, lebar $150 \mathrm{~mm}$ dan tinggi $150 \mathrm{~mm}$. Pengujian dilaksanakan setelah balok beton dipasang dalam keadaan stabil dan sentris dalam dudukan rangka baja yang berukuran $450 \mathrm{~mm}$, kemudian alat penguji lentur dijalankan dengan beban naik berangsur-angsur sampai pada pencatatan hasil lentur tidak bertambah lagi. Untuk mencari nilai kuat lentur beton rumus yang digunakan adalah sebagai berikut :

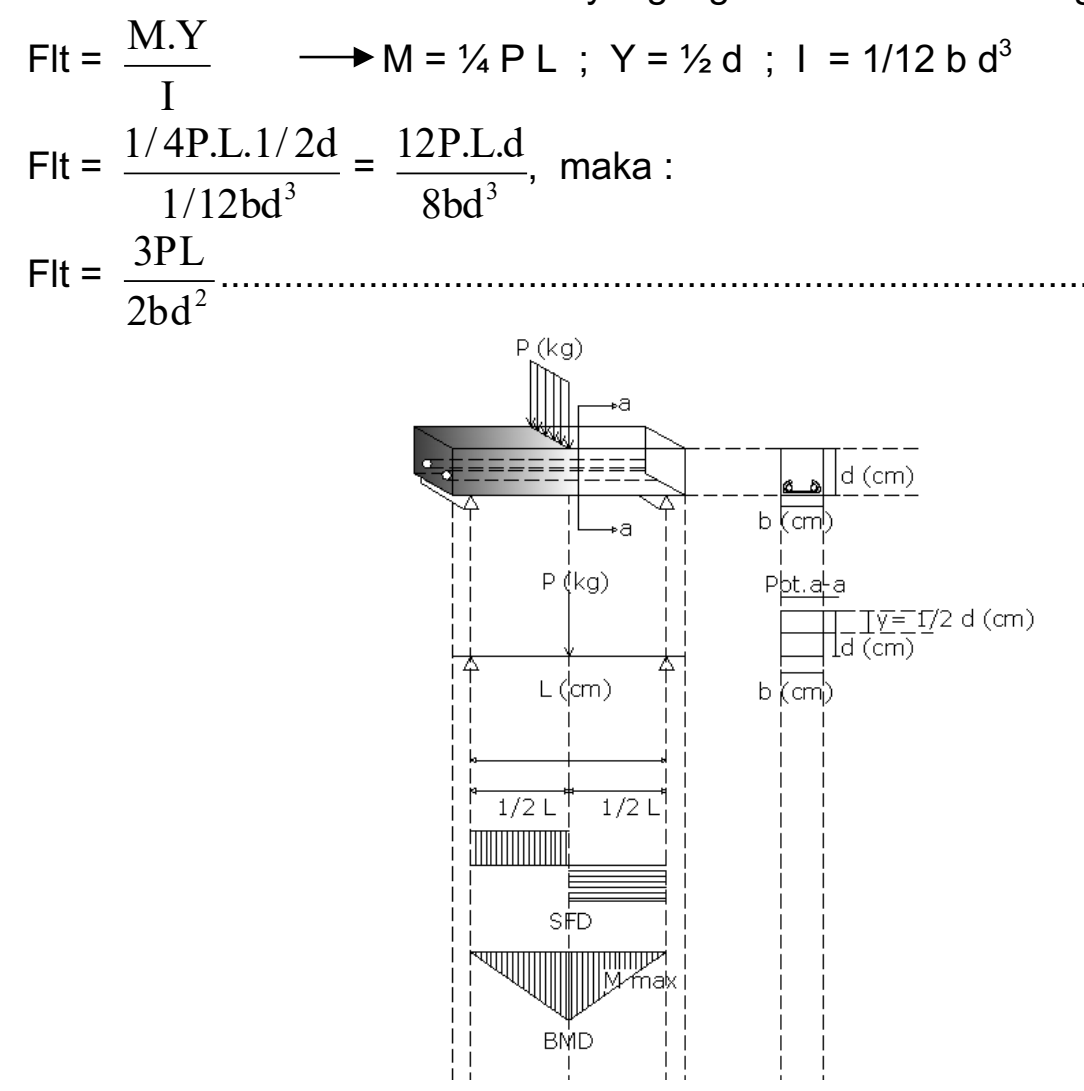

Gambar 2 Gambar uji lentur pada pembebanan balok

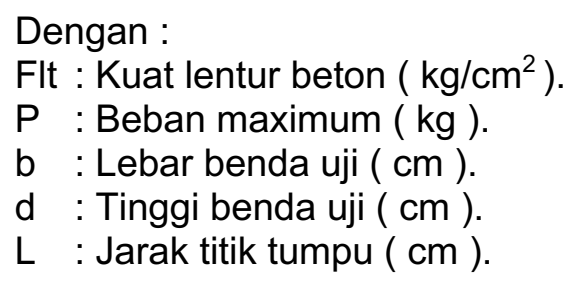

\section{CARA PENELITIAN}

Merupakan tahap pengangkutan dan pengadaan bahan susun beton serta persiapan alat-alat yang akan digunakan diantaranya: (1) Mengayak agregat sesuai dengan aturan yang telah ditetapkan; (2) Menimbang bahan-bahan yang akan digunakan sesuai kebutuhan: (3) Mengecek atau mengontrol alat-alat yang akan digunakan dalam pengujian. 
Pengujian bahan susun merupakan kegiatan pemeriksaan material yang akan digunakan yang meliputi (1) Analisa saringan agregat kasar (batu pecah) dan agregat halus (pasir); (2) Pemeriksaan kadar lumpur; (3) Penyerapan air pada agregat ; (4) Pemeriksaan bahan tambah serat.

Perhitungan kebutuhan bahan susun dalam penelitian ini menggunakan metode " Rode Note No. 4 "Penggunaan bahan tambah yang berupa Pecahan genteng dilakukan dengan cara mencampurkannya pada adukan beton dengan perbandingan $0 \%, 25 \%$, $50 \%, 75 \%$, dan $100 \%$ terhadap volume kerikil. Pembuatan benda uji untuk setiap prosentase sebanyak tiga buah, untuk mengetahui kebutuhan bahan susun yang akan digunakan rumus yang dipakai adalah sebagai berikut :

$$
\frac{\mathrm{S}}{\mathrm{Y}_{\mathrm{s}} \cdot \mathrm{Y}_{\mathrm{air}}}+\frac{\mathrm{P}_{\mathrm{psr}} \cdot \mathrm{S}}{\mathrm{Y}_{\mathrm{psr}} \cdot \mathrm{Y}_{\text {air }}}+\frac{\mathrm{P}_{\mathrm{btpch}} \cdot \mathrm{S}}{\mathrm{Y}_{\mathrm{bt} \mathrm{pch}} \cdot \mathrm{Y}_{\text {air }}}+\frac{\mathrm{A} \cdot \mathrm{S}}{\mathrm{Y}_{\text {air }}}+0,01 \cdot \mathrm{V}=1 \mathrm{~m}^{3}
$$

Dengan :

$\mathrm{Y}_{\mathrm{s}} \quad$ : Berat jenis semen.

$\mathrm{Y}_{\mathrm{psr}} \quad$ : Berat jenis pasir.

$Y_{\text {bt pch }}$ : Berat jenis batu pecah.

$Y_{\text {air }}$ : Berat jenis air.

$\mathrm{V} \quad$ : Prosentase udara dalam beton

$\mathrm{S} \quad$ : Berat semen untuk $1 \mathrm{~m}^{3}$ beton.

Dari rumus diatas maka nilai $S$ diketahui yaitu 0,329 ton, jadi dapat dihitung kebutuhan bahan susun beton untuk $1 \mathrm{~m} 3$ beton. Kontrol berat bahan susun beton total = $2,132 \mathrm{~kg} / \mathrm{m}^{3}<2400 \mathrm{~kg} / \mathrm{m}^{3}$, berarti memenuhi syarat.

Tabel 1 Kebutuhan bahan susun per $\mathbf{m}^{3}$

\begin{tabular}{|c|l|c|}
\hline No & \multicolumn{1}{|c|}{ Bahan susun } & Kebutuhan \\
\hline 1 & Semen $(\mathrm{kg})$ & 329 \\
\hline 2 & Air (liter) & 158 \\
\hline 3 & Agregat halus/pasir $(\mathrm{kg})$ & 658 \\
\hline 4 & Agregat kasar/kerikil $(\mathrm{kg})$ & 987 \\
\hline
\end{tabular}

Tahap-tahap pembuatan benda uji dalam penelitian ini meliputi: (1) Menimbang kebutuhan semen, pasir, batu pecah, air, dan bahan tambah pecahan genteng sesuai dengan kebutuhan; (2) Memasukkan semen, pasir, batu pecah dan bahan tambah pecahan genteng kedalam alat pengaduk (mollen) kemudian air secara bertahap; (3) Pengujian nilai slump adukan; (4) Menuangkan adukan kedalam cetakan sesuai dengan benda uji; (5) Menyimpan adukan selama \pm 1 hari; (6) Pembukaan cetakan.

Perawatan beton sangat penting dilakukan terutama pada waktu awal dimana sejak beton dituangkan atau sejak adukan beton dipadatkan sampai beton dianggap cukup keras. Untuk menjaga agar kondisi beton tetap lembab, kelembaban permukaan beton harus selalu dijaga untuk menjamin proses hidrasi semen yang berlangsung dengan sempurna. Pengujian dilakukan setelah benda uji mencapai umur 14 dan 28 hari yang meliputi 2 pengujian yaitu Pengujian kuat tekan beton dan Pengujian kuat lentur

\section{HASIL PENELITIAN}

\subsection{Pengujian Kuat Tekan Beton}

Pengujian kuat tekan beton dilakukan di Laboratorium Bahan Konstruksi Teknik Universitas Atmajaya, pengujian dilaksanakan setelah beton yang berbentuk silinder dengan diameter $15 \mathrm{~cm}$ dan tinggi $30 \mathrm{~cm}$ berumur 28 hari. Setelah

15 Studi Eksplorasi Limbah Genteng Asal Godean Sebagai Bahan Tambah Pada Campuran Beton (Hery Kristiyanto) 
dilakukan pengujian diperoleh hasil bahwa beton dengan penambahan pecahan genteng 25\% terjadi penurunan kuat tekan beton normal sebesar 32,69\%, sedangkan penambahan pecahan genteng dengan jumlah $50 \%$ menunjukkan penurunan kuat tekan beton sebesar $50,95 \%$, penambahan pecahan genteng $75 \%$ menunjukkan penurunan kuat tekan beton sebesar $52,35 \%$, dan penambahan pecahan genteng $100 \%$ menunjukkan penurunan kuat tekan beton sebesar $62,03 \%$. Sehingga hasil kuat tekan beton maksimal yang dapat diperoleh adalah pada penambahan pecahan genteng $25 \%$ dari berat agregat kasar dengan nilai $67,31 \%$ dari kuat tekan beton normal. Pengujian kuat tekan beton dapat dilihat pada Tabel 5.1.

Tabel 2 Hasil Pengujian Kuat Tekan Beton

\begin{tabular}{|c|c|c|c|c|c|c|c|c|}
\hline \multicolumn{2}{|c|}{$\begin{array}{c}\text { type } \\
\%\end{array}$} & $\begin{array}{l}\text { Tinggi } \\
(\mathrm{cm})\end{array}$ & $\begin{array}{l}\text { Diameter } \\
(\mathrm{cm})\end{array}$ & $\begin{array}{l}\text { Luas } \\
\left(\mathrm{cm}^{2}\right)\end{array}$ & $\begin{array}{c}P \max \\
(\mathrm{KN})\end{array}$ & $\begin{array}{c}\text { K desak } \\
\text { f'c } \\
\left(\mathrm{kg} / \mathrm{cm}^{2}\right) \\
28 \text { hari }\end{array}$ & $\begin{array}{c}\text { f'c } 28 \\
\text { hari } \\
\text { rata- } \\
\text { rata } \\
\left(\mathrm{kg} / \mathrm{cm}^{2}\right)\end{array}$ & $\begin{array}{c}\text { Kenaikan } \\
\text { f'c thd } \\
0 \% \\
\text { umur } 28 \\
\text { hr }\end{array}$ \\
\hline \multirow{3}{*}{$0 \%$} & $N_{I V}$ & 30.30 & 14.97 & 176.08 & 600.00 & 340.756 & \multirow{3}{*}{316.543} & \multirow{3}{*}{$100 \%$} \\
\hline & $\mathrm{N}_{V}$ & 30.10 & 14.98 & 176.31 & 525.00 & 297.763 & & \\
\hline & $\mathrm{N}_{\mathrm{VI}}$ & 30.00 & 15.00 & 176.79 & 550.00 & 311.111 & & \\
\hline \multirow{3}{*}{$25 \%$} & $A_{I V}$ & 30.00 & 14.82 & 172.57 & 335.00 & 194.126 & \multirow{3}{*}{213.070} & \multirow{3}{*}{$67.31 \%$} \\
\hline & $A_{v}$ & 30.10 & 14.93 & 175.14 & 420.00 & 239.809 & & \\
\hline & $\overline{A_{v 1}}$ & 30.10 & 14.94 & 175.37 & 360.00 & 205.275 & & \\
\hline \multirow{3}{*}{$50 \%$} & $\mathrm{~B}_{\mathrm{IV}}$ & 30.20 & 15.00 & 176.79 & 240.00 & 135.758 & \multirow{3}{*}{155.271} & \multirow{3}{*}{$49.05 \%$} \\
\hline & $\mathrm{B}_{V}$ & 30.00 & 14.95 & 175.61 & 285.00 & 162.292 & & \\
\hline & $\mathrm{B}_{\mathrm{VI}}$ & 30.20 & 14.96 & 175.84 & 295.00 & 167.762 & & \\
\hline \multirow{3}{*}{$75 \%$} & $\mathrm{C}_{\mathrm{IV}}$ & 30.30 & 15.00 & 176.79 & 255.00 & 144.242 & \multirow{3}{*}{150.842} & \multirow{3}{*}{$47.65 \%$} \\
\hline & $\mathrm{C}_{V}$ & 30.20 & 15.00 & 176.79 & 280.00 & 158.384 & & \\
\hline & $\mathrm{C}_{\mathrm{VI}}$ & 30.20 & 15.00 & 176.79 & 265.00 & 149.899 & & \\
\hline \multirow{3}{*}{$100 \%$} & $D_{\text {IV }}$ & 30.20 & 14.97 & 176.08 & 155.00 & 88.029 & \multirow{3}{*}{120.176} & \multirow{3}{*}{$37.97 \%$} \\
\hline & $D_{v}$ & 30.30 & 14.95 & 175.61 & 260.00 & 148.056 & & \\
\hline & $\mathrm{D}_{\mathrm{VI}}$ & 30.00 & 15.00 & 176.79 & 220.00 & 124.444 & & \\
\hline
\end{tabular}

\subsection{Pengujian Kuat Lentur Beton}

Pengujian kuat lentur dilaksanakan di laboratorium Bahan Konstruksi Teknik Universitas Cokroaminoto Yogyakarta, pengujian kuat lentur dilakukan setelah beton dengan ukuran $15 \times 15 \times 60 \mathrm{~cm}$ berumur 28 hari. Dari semua sampel benda uji yang diuji kuat lenturnya, diperoleh hasil bahwa beton dengan bahan tambah Pecahan genteng sebesar $75 \%$ mengalami penurunan kuat lentur beton yang paling sedikit dibandingkan dengan beton dengan campuran $25 \%, 50 \%$ dan $100 \%$, yaitu beton dengan penambahan pecahan genteng sebesar $75 \%$ mengalami penurunan sebesar $6,88 \%$ terhadap beton normal. Untuk hasil pengujian kuat lentur beton dapat dilihat pada Tabel 5.2. dan Gambar 5.2. 
Tabel 3 Hasil Pengujian Kuat Lentur Beton

\begin{tabular}{|c|c|c|c|c|c|c|c|c|c|}
\hline $\begin{array}{c}\text { Kadar } \\
\text { pecaha } \\
\mathrm{n} \\
\text { genten } \\
\mathrm{g}\end{array}$ & $\begin{array}{c}\text { No. } \\
\text { Bend } \\
\text { a } \\
\text { Uji }\end{array}$ & $\begin{array}{c}\text { Panjan } \\
\mathrm{g}(\mathrm{cm})\end{array}$ & $\begin{array}{l}\text { Leba } \\
\mathrm{r}(\mathrm{B}) \\
(\mathrm{cm})\end{array}$ & $\begin{array}{l}\text { Tingg } \\
\mathrm{i}(\mathrm{D}) \\
(\mathrm{cm})\end{array}$ & $\begin{array}{c}\text { Beba } \\
n \\
\text { Max } \\
(\mathrm{P}) \\
(\mathrm{KN})\end{array}$ & $\begin{array}{l}\text { Jarak } \\
\text { Tump } \\
\text { u (L) } \\
(\mathrm{cm})\end{array}$ & $\begin{array}{c}\text { Flt } \\
\left(\mathrm{kg} / \mathrm{cm}^{2}\right. \\
)\end{array}$ & $\begin{array}{c}\text { Flt rt } \\
\left(\mathrm{kg} / \mathrm{cm}^{2}\right. \\
)\end{array}$ & $\begin{array}{c}\text { Kenaika } \\
\text { n Thd } \\
0 \%\end{array}$ \\
\hline \multirow{2}{*}{$0 \%$} & $N_{1}$ & 60.50 & $\begin{array}{c}15.0 \\
0\end{array}$ & 15.23 & 35.00 & 55 & 82.991 & \multirow{2}{*}{83.917} & \multirow{2}{*}{$\begin{array}{c}100.00 \\
\%\end{array}$} \\
\hline & $\mathrm{N}_{\mathrm{II}}$ & 59.90 & $\begin{array}{c}15.0 \\
0\end{array}$ & 15.17 & 35.50 & 55 & 84.844 & & \\
\hline \multirow{2}{*}{$25 \%$} & $A_{l}$ & 59.80 & $\begin{array}{c}14.9 \\
9 \\
\end{array}$ & 15.75 & 30.10 & 55 & 66.782 & \multirow{2}{*}{64.291} & \multirow{2}{*}{$76.61 \%$} \\
\hline & $A_{\|}$ & 65.00 & $\begin{array}{c}15.5 \\
6 \\
\end{array}$ & 15.29 & 27.25 & 55 & 61.801 & & \\
\hline \multirow{2}{*}{$50 \%$} & $\mathrm{~B}_{1}$ & 60.20 & $\begin{array}{c}15.6 \\
1 \\
\end{array}$ & 15.23 & 28.00 & 55 & 63.798 & \multirow{2}{*}{66.970} & \multirow{2}{*}{$79.80 \%$} \\
\hline & $\mathrm{B}_{\|}$ & 59.40 & $\begin{array}{c}15.1 \\
6 \\
\end{array}$ & 15.00 & 29.00 & 55 & 70.141 & & \\
\hline \multirow{2}{*}{$75 \%$} & $\mathrm{C}_{1}$ & 60.10 & $\begin{array}{c}15.4 \\
9\end{array}$ & 15.26 & 32.00 & 55 & 73.189 & \multirow{2}{*}{78.146} & \multirow{2}{*}{$93.12 \%$} \\
\hline & $\mathrm{C}_{\|}$ & 59.50 & $\begin{array}{c}14.9 \\
6\end{array}$ & 15.24 & 35.00 & 55 & 83.104 & & \\
\hline \multirow{2}{*}{$100 \%$} & $D_{1}$ & 59.70 & $\begin{array}{c}15.0 \\
0\end{array}$ & 15.37 & 30.00 & 55 & 69.845 & \multirow{2}{*}{69.118} & \multirow{2}{*}{$82.36 \%$} \\
\hline & $D_{\|}$ & 60.20 & $\begin{array}{c}15.2 \\
9\end{array}$ & 15.23 & 29.40 & 55 & 68.390 & & \\
\hline
\end{tabular}

\subsection{Berat Volume (Berat Jenis Beton)}

Berat volume beton ringan sangat tergantung pada berat jenis dan gradasi agregat yang dipakai (Kardiyono Tjokrodimulyo, 1996). Dari tabel pemeriksaan diperoleh nilai berat volume sebesar $2,325 \mathrm{~kg} / \mathrm{cm}^{3}$ untuk yang beton normal dan maksimal $2,131 \mathrm{~kg} / \mathrm{cm}^{3}$ penambahan pecahan Genteng $25 \%$. Sedangkan pada penambahan pecahan genteng $75 \%$ berat volumenya menjadi $1,977 \mathrm{~kg} / \mathrm{cm}^{3}$ sehingga bisa digolongkan sebagai beton ringan. Seperti terlihat dalam Tabel 5.3.

\subsection{Hubungan berat volume dengan kuat tekan beton}

Berdasarkan pengujian berat volume dan kuat tekan beton (Tabel 5.4.) menunjukkan bahwa penurunan berat volume akan diikuti dengan penurunan kuat tekan beton. Hal ini disebabkan karena semakin menurunnya berat volume beton maka beton akan bersifat lebih porous yaitu lebih banyak rongga-rongga udara yang ada dalam beton sehingga beton cenderung lebih lemah sehingga kuat tekannyapun cenderung semakin menurun.

\subsection{Hubungan berat volume dengan kuat lentur beton.}

Dari hasil perhitungan berat volume dan kuat lentur beton ringan pada diperoleh hasil seperti pada Tabel 5.5. menunjukkan hasil bahwa naik-turunnya berat volume tidak mempengaruhi secara langsung besar-kecilnya kuat lentur pada beton, terbukti pada penambahan pecahan genteng $25 \%$ dengan berat volume sebesar $2,131 \mathrm{~kg} / \mathrm{cm}^{3}$ memiliki kuat lentur $6,429 \mathrm{MPa}$, sedangkan pada 
penambahan pecahan genteng $100 \%$ memiliki berat volume $1,898 \mathrm{~kg} / \mathrm{cm}^{3}$ lebih ringan tetapi memiliki kuat lentur lebih tinggi yaitu sebesar 6,912 MPa.

\section{Tabel 4 Hasil Pengujian Berat Volume (Berat Jenis Beton)}

\begin{tabular}{|c|c|c|c|c|c|}
\hline \multicolumn{2}{|c|}{$\%$} & $\begin{array}{c}\text { Volume } \\
\left(\mathrm{cm}^{3}\right)\end{array}$ & Berat $(\mathrm{kg})$ & $\begin{array}{c}\text { Berat } \\
\text { Volume }(x \\
\left.10^{3}\right) \\
\left(\mathrm{kg} / \mathrm{cm}^{3}\right)\end{array}$ & $\begin{array}{c}\text { Berat Volume } \\
\text { Rata-rata }(\mathrm{x} \\
\left.10^{3}\right)\left(\mathrm{kg} / \mathrm{cm}^{3}\right)\end{array}$ \\
\hline \multirow{5}{*}{$0 \%$} & A & 5335.20 & 12.46 & 2.335 & \multirow{5}{*}{2.325} \\
\hline & $A_{l}$ & 13821.23 & 31.80 & 2.301 & \\
\hline & $\mathrm{B}$ & 5307.07 & 12.38 & 2.333 & \\
\hline & $A_{\| I}$ & 13630.25 & 32.10 & 2.355 & \\
\hline & $\mathrm{C}$ & 5303.57 & 12.20 & 2.300 & \\
\hline \multirow{5}{*}{$25 \%$} & $\mathrm{~A}$ & 5177.05 & 11.50 & 2.221 & \multirow{5}{*}{2.131} \\
\hline & $\mathrm{B}_{\mathrm{I}}$ & 14118.33 & 29.50 & 2.089 & \\
\hline & $B$ & 5271.70 & 11.56 & 2.193 & \\
\hline & $\mathrm{B}_{\|}$ & 15464.31 & 30.00 & 1.940 & \\
\hline & $\mathrm{C}$ & 5278.77 & 11.68 & 2.213 & \\
\hline \multirow{5}{*}{$50 \%$} & $A$ & 5338.93 & 11.02 & 2.064 & \multirow{5}{*}{2.090} \\
\hline & $\mathrm{C}_{1}$ & 14311.97 & 30.00 & 2.096 & \\
\hline & $B$ & 5268.27 & 10.96 & 2.080 & \\
\hline & $\mathrm{C}_{\| 1}$ & 13507.56 & 28.70 & 2.125 & \\
\hline & $\mathrm{C}$ & 5310.49 & 11.06 & 2.083 & \\
\hline \multirow{5}{*}{$75 \%$} & $\bar{A}$ & (5356.61 & 10.62 & 1.983 & \multirow{5}{*}{1.977} \\
\hline & $D_{1}$ & 14206.28 & 27.00 & 1.901 & \\
\hline & $B$ & 5338.93 & 10.68 & 2.000 & \\
\hline & $D_{\text {II }}$ & 13565.43 & 27.70 & 2.042 & \\
\hline & C & 5338.93 & 10.46 & 1.959 & \\
\hline \multirow{5}{*}{$100 \%$} & $\bar{A}$ & 5317.59 & 9.38 & 1.764 & \multirow{5}{*}{1.898} \\
\hline & $\mathrm{E}_{\mathrm{I}}$ & 13763.84 & 27.80 & 2.020 & \\
\hline & $\mathrm{B}$ & 5320.96 & 10.22 & 1.921 & \\
\hline & $E_{\|}$ & 14018.58 & 26.50 & 1.890 & \\
\hline & C & 5303.57 & 10.06 & 1.897 & \\
\hline
\end{tabular}

Tabel 5 Perbandingan berat volume dan kuat tekan beton ringan

\begin{tabular}{|c|c|c|}
\hline $\begin{array}{c}\text { Penambahan } \\
\text { Pecahan } \\
\text { Genteng }\end{array}$ & $\begin{array}{c}\text { Berat } \\
\text { Volume } \\
(\mathrm{Kg} / \mathrm{cm} 3)\end{array}$ & $\begin{array}{c}\text { Kuat } \\
\text { Tekan } \\
(\mathrm{MPa})\end{array}$ \\
\hline $0 \%$ & 2.325 & 31.654 \\
\hline $25 \%$ & 2.131 & 21.307 \\
\hline $50 \%$ & 2.090 & 15.527 \\
\hline $75 \%$ & 1.977 & 15.084 \\
\hline $100 \%$ & 1.898 & 12.018 \\
\hline
\end{tabular}




\section{Tabel 6 Perbandingan hasil berat volume dan kuat lentur beton ringan}

\begin{tabular}{|c|c|c|}
\hline $\begin{array}{c}\text { Penambahan } \\
\text { Pecahan } \\
\text { Genteng }\end{array}$ & $\begin{array}{c}\text { Berat } \\
\text { Volume } \\
\text { (Kg/cm3) }\end{array}$ & $\begin{array}{c}\text { Kuat } \\
\text { Lentur } \\
\text { (MPa) }\end{array}$ \\
\hline $0 \%$ & 2.325 & 8.392 \\
\hline $25 \%$ & 2.131 & 6.429 \\
\hline $50 \%$ & 2.090 & 7.423 \\
\hline $75 \%$ & 1.977 & 7.815 \\
\hline $100 \%$ & 1.898 & 6.912 \\
\hline
\end{tabular}

\section{KESIMPULAN}

1. Berat jenis beton dengan bahan tambah pecahan genteng tertinggi pada umur 28 hari maksimal $2,131 \mathrm{~kg} / \mathrm{cm}^{3}$ pada penambahan serat $25 \%$.

2. Kuat tekan beton dengan penambahan pecahan genteng berkisar $102,2 \mathrm{~kg} / \mathrm{cm}^{2}$ sampai $213,1 \mathrm{~kg} / \mathrm{cm}^{2}$ dengan penurunan maksimal $62,03 \%$ terhadap beton normal. Kuat lentur beton $78,146 \mathrm{~kg} / \mathrm{cm}^{2}$ dengan penurunan maksimal $23,39 \%$ terhadap beton normal.

3. Dari hasil komparasi menunjukkan bahwa beton dengan penambahan pecahan genteng sebagai bahan pengganti agregat kasar terbukti tidak bisa meningkatkan mutu beton agar lebih baik, hal ini dikarenakan semakin banyak prosentase penambahan pecahan genteng maka semakin besar pula serapan air sehingga menyebabkan kepadatan beton semakin rendah dan terdapat banyak rongga-rongga didalam beton, sehingga kuat tekan dan kuat lentur beton menjadi lebih rendah.

\section{DAFTAR PUSTAKA}

Anonim,1971,Peraturan Beton Bertulang Indonesia ( $P B B I$ ), Penerbit Direktorat Penyelidikan Masalah Bahan Bangunan, Dirjen Cipta Karya, Dep. PU, Bandung Anonim,1982,Peraturan Umum Bangunan Indonesia (PUBI), Penerbit Direktorat Penyelidikan Masalah Bahan Bangunan, DPU, Bandung.

Anonim,1990, Standar SK SNI M-62-1990-03, Metode dan Perawatan Benda Uji Beton di Laboratorium, Yayasan LPMB, Bandung.

Anonim,1990, Standar SK SNI M-60-1990-03, Metode Pengujian Kuat Tarik Belah Beton, Yayasan LPMB, Bandung.

Dipohusodo,1991, Struktur Beton Bertulang, Penerbit PT. Gramedia Pustaka Utama, Jakarta.

Heri Fitriono,2001, Tinjauan Penggunaan Batu Putih Sebagai Agregat Kasar Terhadap Kuat Desak Beton. TA, JTS FT, Universitas Cokroaminoto Yogyakarta.

Syafiq zainudin. M, 2003, Kajian Kuat Tekan Beton Dengan Bahan Susun Agregat Kasar Batu Putih ( calsidon ) Desa Mulo Kecamatan Wonosari Kabupaten Gunung Kidul. TA, JTS FT, Universitas Cokroaminoto Yogyakarta.

Tjokrodimulyo, K., 1996, Teknologi Beton, Buku Ajar, Penerbit Nafiri, Yogyakarta. Mulyono Tri,, 2004, Teknologi Beton, Buku Ajar, Penerbit Andi, Yogyakarta. 